\title{
TIME MANAGEMENT FOR BETTER JOB PERFORMANCE: AN ANALYSIS FROM AL-WASATIYYAH PERSPECTIVE
}

\author{
Rafikul Islam $^{1^{*}}$, Md. Yousuf Ali ${ }^{2}$, and Noor Mohammad Osmani ${ }^{3}$ \\ ${ }^{1}$ Department of Business Administration, Kulliyyah of Economics and Management \\ Sciences, International Islamic University Malaysia, Jalan Gombak, \\ 53100 Kuala Lumpur, Malaysia \\ ${ }^{2}$ International Institute of Islamic Thought and Civilisation, International Islamic \\ University Malaysia, No. 24, Persiaran Tuanku Syed Sirajuddin, Taman Duta, \\ 50480 Kuala Lumpur, Malaysia \\ ${ }^{3}$ Department of Quran and Sunnah, Kulliyyah of Islamic Revealed Knowledge and \\ Human Sciences, International Islamic University Malaysia, Jalan Gombak, \\ 53100 Kuala Lumpur, Malaysia
}

*Corresponding author: rislam@iium.edu.my

Published online: 4 June 2021

To cite this article: Islam, R., Ali, M. Y., \& Osmani, N. M. (2021). Time management for better job performance: An analysis from al-wasatiyyah perspective. Asian Academy of Management Journal, 26(1), 171-196. https://doi.org/10.21315/aamj2021.26.1.7

To link to this article: https://doi.org/10.21315/aamj2021.26.1.7

\begin{abstract}
Managing time means engaging activities that generate greater benefits to human beings. To a Muslim, benefits encompass for both worlds, i.e., life in this mundane world as well as life in the hereafter. Previous research on time management resulted in a variety of findings depending on the aspects under study. The objective of this research is to investigate the components of time management that have significant relationship with job performance, especially in the context of Malaysian employees. This research also intends to relate the concepts and attributes of "al-wasatiyyah" that have direct relationship to job performance. To pursue the research objectives, 223 employees working in different sectors in Malaysia were contacted. The researchers found that certain time management factors namely "prioritisation of tasks," "usage of schedules," and "time management instrument" sustained statistically significant positive relationships to job performance. Meanwhile, the al-wasatiyyah variables that have been found to have statistically significant positive relationships to job performance are "working with sincerity/pure intention (niyyah)," "following the middle path to avoid excessiveness in working place (wasatan)," "practicing values in working place (qiam)," and "ensuring fairness in

(C) Asian Academy of Management and Penerbit Universiti Sains Malaysia, 2021. This work is licensed under the terms of the Creative Commons Attribution (CC BY) (http://creativecommons. org/licenses/by/4.0/).
\end{abstract}


task assignment (adl)." These findings have important implications. Most importantly, managers of organisations can practice them to motivate employees in order to enhance their job performance which by and large will improve the performance of the whole organisation in the long run.

Keywords: time management, time management factors, job performance, Islamic perspective, al-wasatiyyah

\section{INTRODUCTION}

Allah (swT) says (Al-Asr, 103: 1-3):

By (the token of) time (through the Ages), verily man is in loss, except those who have faith and do righteous deeds and (join together) in the mutual teaching of truth and of patience and constancy (Al-Qur'an, 2016).

In line with the above Qur'anic verses, human beings are required to discipline themselves by underscoring the importance of time. They must be prompt in doing good deeds, which will increase their faith and subsequently, enable them to gain Allah's pleasure and mercy. They have to remember that on the Day of Judgement, they will be asked how they spent their time, lives, wealth, and knowledge. In other words, they will be questioned on how they spent everything that Allah (SWT) has given to them as narrated [by Abdullah bin Masud (RA)] in the following hadith.

Allah's Messenger (peace be upon him) said:

A man shall be asked concerning five things on the Day of Resurrection: concerning his life, how he spent it; concerning his youth, how he grew old; concerning his wealth, how he acquired it, and in what way he spent it; and what was it that he did with the knowledge that he had (Sunan Al-Tirmidhi, vol. 4, book 11, hadith no. 2416).

The above hadith reiterates that time management is important, beneficial, and effective for individuals and organisations. In order to balance our daily lives, we need to be able to organise and utilise our time wisely. Without good time management skills, we can easily fall behind in fulfilling our responsibilities and feeling exasperated. Time is a valuable resource whereby our attitude to it and the way we use it makes the difference between success and failure, fitness and poor health, peace of mind and anxiety or depression (Jone, 1997). Since time always passes at a constant speed, one has to care for the time allocated to him/her. The 
amount of time daily, monthly, or yearly is the same for all. It is said that those who care for their time are the ones who make great achievements in their personal and professional lives, and they do realise that time is not enough for doing all what they want to do. In contrast, those who do not care for achievements are the ones who consider time to be of little value (Al-Jeraisy, 2008). Ironically, in spite of its great importance, time is the most wasted and the least concerned element at both the individual as well as organisational levels.

One of the critical issues in management today is how to manage time. Time is a very unique commodity. It cannot be borrowed, rented, or bought. It is irreplaceable and execution of anything requires it. It is found that proper management of time increases efficiency, personal and professional satisfaction, and decreases stress (Claessens et al., 2007). In essence, time management is vital for overall wellbeing.

Macan et al. (1990) found that those who obtained higher time management behaviour scores will experience less ambiguity concerning their role, less somatic tension, greater satisfaction in job as well as life, and higher overall performance. The authors also discovered four factors that define time management behaviour - setting goals and priorities; mechanics which includes planning and scheduling; perceived control of time; and preference for disorganisation.

Amponsah-Tawiah et al. (2018) found in their cross-sectional study that in Ghana, many employees have poor time management skills and consequently their productivity was low. In other words, to improve productivity in the industrial sector of Ghana, employees must pay attention on how they use their time in the workplace.

From the Islamic standpoint, time is a precious amanah from Allah (SWT). Proper utilisation of time increases efficiency, personal and professional satisfaction, and decreases stress from workload. It also leads to success for worldly pursuits and secure eternal bliss in the hereafter. Since time is limited in life, it must be utilised in the best possible manner so that eternal success can be attained. According to Al-Jeraisy (2008), a Muslim's life involves two elements, i.e., worshipping and earning a living. He/she should use his/her time wisely and efficiently in daily life and should not render his/her deeds in vain as the Qur'an (47: 33) says: "O you who believe! Obey Allah, and obey the Messenger and render not vain your deeds."

This present empirical work deals with time management, job performance, and al-wasatiyyah concept in Islam. Al-wasatiyyah is an Arabic word derived from the word wasat which means moderation, middle path, or balanced way (Hanapi, 
2014). In the context of the Qur'an, ummatan wasatan (Al-Baqarah, 2:143) refers to the balanced Islamic community or a just nation in every aspect of life. Al-wasatiyyah is a guide for a Muslim in achieving success in his/her worldly life as well as life after death. It is the opposite of extremism and liberalism. In fact, the concept of al-wasatiyyah has become popular in contemporary time amongst Muslims (Bakir \& Othman, 2017). Hence, the present study aims (1) to investigate the effects of time management on job performance, (2) to find out the factors that affect job performance, and (3) to connect them with the role of al-wasatiyyah in time management for better job performance.

In the Malaysian context, not many researches have been conducted involving time management and job performance. Nonetheless, the few which were found in literature are briefly reported here. Abduljabbar et al. (2012) investigated the relationship between time management and job performance for the administrative staff of the Universiti Tenaga National in Malaysia. By means of a survey on 220 respondents, the researchers found positive relationships between time planning, time attitude, and job performance. However, as expected, they found a negative relationship between time wasters and job performance. Another study discovered that to organise or execute any event successfully, good time management is essential (Ahmad et al., 2012). The authors, through an empirical study on 65 event managers in Malaysia, found significant positive correlation between time management and event management performance. Most of the respondents disclosed that time management affected their job performance.

Meanwhile, there has been a wide range of research on matching graduates' competency and employability skills required in the job market (Hamid et al., 2014; Kenayathulla et al., 2019). A recent study conducted by Kenayathulla et al. (2019) found that there was a significant gap between the skills possessed by the graduates in their hospitality program and the required skills in the hospitality industry. The researchers recommended that graduates should be equipped with the 21st century required skills including problem solving and decision making, risk taking, correlation, organisation, and time management. Johari et al. (2019) investigated structural relationship between job itself, employee well-being, and job performance for various public agencies in Malaysia. In particular, the researchers found that employee well-being accounted for $41.8 \%$ variation in job performance, but the research did not include the time management factor to test its relationship with job performance.

Overall, in the Malaysian context, there is a clear dearth of studies on time management from al-wasatiyyah perspective and, in fact, very little work has been done on the integration of the philosophy of al-wasatiyyah with time management. 
Therefore, the present research investigates the relationship between time management, al-wasatiyyah, and job performance to fill up this research gap.

\section{LITERATURE REVIEW}

\section{Time Management}

Research findings are abounding with different contents on time management in the areas of academics, leadership, psychology, and organisational behaviour. As the objective of this research is to identify the relationship between time management and job performance in the organisation from al-wasatiyyah perspective, it needs to depict certain issues pertaining to time management.

Sarfraz (2017) dispels the myth that transformational, transactional, and other types of leaders have similar time management skills. The researcher connected eight time management categories with the nine leadership styles based on each style's nature. The researcher concluded that the linkage between leadership style and time management skills can bring greater understanding on the parts of the leaders on how they should design their leadership strategies. In a recent study, Janeslätt et al. (2018) developed a scale to assess time management skills of people who require occupational therapy. A total of 238 respondents participated in their study of which 94 had impaired time management skills due to mental disorders.

Previous literature suggests developing skills for better time management which include the capability of identifying priorities, having achievable goals, remain organised, and monitor one's very own progress (Claessens et al., 2007). A number of researchers have discussed about the components of effective time management. A group of researchers of the Eastern Illinois University developed seven components of effective time management. On the other hand, researchers at the University of Central Florida developed 16 components related to time management (Pierce \& Jussila, 2011). The components are essentially related with managing goals, tasks, prioritisation of tasks, usage of schedule, procrastination management, and reminder system. These components have strong links with the pioneering model on time management developed by Macan (1994).

Konig and Kleinmann (2005) found that people became most active in carrying out the projects when deadlines loom. This phenomenon is known as "time discounting" which is the main cause for deadline rush. The authors also observed that, in general, people preferred smaller but sooner reward over larger but later reward. This typical behaviour of people is more accurately portrayed 
by a hyperbolic function rather than an exponential one. The observation has also been supported by some earlier researchers such as Koch and Kleinmann (2002). On a related topic, several researchers explored the relationship between dispositional characteristics and time management. Propensities to procrastinate, impatience, and polychonicity (multitasking) are treated as common dispositional characteristics (Bond \& Feather, 1988; Francis-Smythe \& Robertson, 1999) found among employees.

A number of studies have been conducted linking time management and academic performance. Using the time management model originally developed by Britton and Glynn (1989), Britton and Tesser (1991) tested the effects of certain time management practices on students' academic achievements. A principal component analysis on a 35 itemised list provided three components, namely shortrange planning, time attitudes, and long-range planning. The researchers found significant positive correlation between academic achievement (such as CGPA) and time attitude. Oran (2009) has shown how students' study time in a semester can be saved by re-structuring the class-schedules. If the restructured classschedules are implemented, the author is of the opinion that about a month's time can be saved in a typical semester. Though, it is basically a research on students' class schedule, time is used as a parameter and time management concepts have been used to delineate the propositions.

Sun and Yang (2009) investigated the relationship between time management practices of higher secondary students in the Shenyang region of China and their learning outcomes. The authors revealed that students felt pressured that are coming from different sources. The strongest pressure was to do well in school and to pass the national college entrance examinations. Then, another strong pressure was parents' pressure followed by pressure from the greater society. Surprisingly, the students felt that the least pressure came from their school and teachers.

Karakose (2015) found positive correlation between medical students' time management skills and their academic performance. In particular, the author found that female students demonstrated superior skills in time management compared to their male counterparts. In the meantime, a research on time management in academic setting also suggest that developing the school principal's time management capacities may be a worth-while strategy in increasing higher priority tasks and reducing stress (Grissom et al., 2015). The researchers derived this strategy from their empirical study that examined time management among 300 school principals in the USA and linked time management to their key outcomes. 
Kouali and Pashiardis (2015) also conducted another empirical research on Cypriot primary school principals and found three different time management profiles of principals. They are centralised monochrons, procrastinative managers, and decentralised polychrons. They maintain that principals who adopt decentralised polychrons manage time better than others. On the other hand, Alvarez Sainz et al. (2019) observed that students lack sound time management skills. They deduce that it is the educational system that should ensure developing these skills among students. The authors also contend that students focus only on short-term planning and lack habits and attitudes for long term.

\section{Time Management and Job Performance}

A number of researchers have also investigated the relationship between time management and job performance. Woodward and Geissler (1999), through an empirical research, identified the management skills required for students in the textile programs, i.e., to be successful as managers in the textile industry. The respondents, who were managers in the same industry, said that the new entrylevel managers must have the following skills especially leadership, problem solving, decision making, and time management. Overall, from the survey, it was highlighted that time management is an important skill that is necessary in order to perform well in the textile industry.

Green and Skinner (2005) conducted a survey on 233 participants and found that the majority of the participants recorded significant improvement of performance in the following areas, i.e., planning, prioritising, and assertiveness. They also found that the median improvement of personal effectiveness was $20 \%$. In the context of selected parastatals in Kenya, Njagi and Malel (2012) found a statistically positive correlation of 0.674 between time management and job performance. The researchers concluded that since there was significant positive correlation between time management and job performance, therefore, adequate training should be provided to the managers on time management. In another related research, Afsaneh et al. (2019) investigated the extent time management skills are associated with self-efficacy. The researchers found that poor time management, planning and organisation skills have a negative effect on self-efficacy.

\section{Al-Wasatiyyah}

Al-wasatiyyah is an Arabic word which means "an individual or group of attributes and practices as being moderate and adjusted" (Yousif, 2015). It additionally implies a disposition, which is in opposition to being indulged in extremism and excessiveness. Other words that are commonly used for al-wasatiyyah are balanced, 
standard, intermediacy, midpoint, and adequate (Hassan, 2013). Al-wasatiyyah is more meaningful today due to the increased religio-political difficulties postured by the rising ebbs and flows of religious extremism, radicalism, and savagery (Mujani et al., 2015).

Islamic moderation is a concept derived directly from four sources. The main source is the Qur'an that portrays the ummah as ummatan wasatan (Al-Baqarah, 2: 143). The second source is the Qur'anic directive to evade fanatic religious practices (Al-Anaam, 6: 153). The prophetic standard is the third source that expresses "the best of undertakings is that which is most just (or more adjusted)" and the last source is the significance that Islam provides for the quest for far reaching information of the world we live in so that our life is edified by such learning and wisdom.

\section{Time Management from Al-Wasatiyyah Perspective}

As mentioned previously, the term al-wasatiyyah has been derived from the word wasat in Arabic which means to be moderate or to be in the middle. Islam encourages to be balanced in all activities that we do in our daily life including talking, eating, drinking, sleeping, spending, and so on. Extreme practices in any of these activities can bring negative consequences. This means that we need to make a balance in our lives. Regarding spending, Allah (SwT) says (Al-Isra, 17: 29): "And do not make your hand (as) chained to your neck (spending) or extend it completely and (thereby) become blamed insolvent."

In some related verses, Allah (SWT) says:

And those who, when they spend, are neither extravagant nor miserly, and it (i.e., their spending) is moderate in between (the two extremes) (Al-Furqan, 25: 67).

And fight in the cause of Allah (against) those who fight you, (but) do not transgress limits, indeed Allah does not love the transgressors (AlBaqarah, 2: 190).

The above verses amply underscore the importance of striking a balance in all our worldly activities. Since time is required to carry out all activities, therefore, there is a need to be mindful of not spending excessive time on certain activity. Many Qur'anic verses and hadiths are related with time management that encouraged people to use their time wisely. Several theories have also been discussed by scholars that show the importance of time in every sphere of human life. 
Life in this world is temporary. People do not know when death has been destined for them. Everyone must value time for the obedience of Allah (swT). For the success of human life, nobody should waste his/her valuable time. Al-Jeraisy (2008) considers time as one of the gifts that Allah (SWT) has given to individuals. According to the Islamic teachings, Allah's endowments are incalculable. Allah (SWT) says in the Qur'an: "And if you would count the favour of Allah you cannot reckon it. Lo! Allah is indeed Forgiving, Merciful" (An-Nahl, 16: 18).

The Qur'an stresses the value of time in many ways and contexts. For instance, deeds and their means, administration and organisation, universe and creation, and creation-creator relationship are all related to the time dimension. Allah (SWT) says: "Surely, the number of months according to Allah is twelve (as written) in the Book of Allah on the day He created the Heavens and the Earth, of which there are four sacred months" (At-Tawbah, 9: 36). One hadith explains the above as narrated by Sayyidina Abu Bakr As-Siddiq (RA):

The Prophet (PBUH) said: Time has come back to its original state which it had when Allah created the Heavens and the Earth; the year is of twelve months, four of which are sacred. Three of them are in succession: Dhul Qa'dah, Dhul Hijjah, and Muharram, and (the fourth being) Rajab which stands between Jumad (ath-thani) and Shaban" (Bukhari, vol. 6, book 60, no. 184).

From the Qur'an, we also find that many acts of worships are related with time. For example, Allah (SWT) says in the Qur'an about starting the month of fasting (Ramadan):

The month of Ramadan in which was revealed the Qur'an, a guidance for mankind, and clear proofs of the guidance, and the Criterion (of right and wrong). And whosoever of you are present and witness the month let him fast in the month (Al-Baqarah, 2: 185).

And also He mentioned the same for prayers by saying: "Establish worship (prayers) at the going down of the sun until the dark of night and (the recital of) the Qur'an at dawn. Lo! (the recital of) the Qur'an at dawn is ever witnessed" (Al-Isr'a 17: 78).

The Qur'an has accentuated on overseeing time by relating it to the movement of the day and the night. Allah (SWT) says in the Qur'an: "Behold! In the creation of the Heavens and the Earth, and the alternation of Night and Day, there are indeed Signs for men of understanding" (Al-Imran, 3: 190). 
We should comprehend the wisdom and the motivation behind time and to figure out how we can utilise it viably for our advancement, development, and improvement and not to fall prey to its negativities of either squandering or spending it in futile manner.

Hassan (2013) provides a conceptual framework of al-wasatiyyah, where he stresses that the structure of al-wasatiyyah stands on three pillars: excellence and goodness; justice; and balance/moderation. Kamali (2010) also contends that al-wasatiyyah is a multi-dimensional concept. However, there are no unique set of dimensions of al-wasatiyyah where opinions of all the scholars have converged. For example, Kamali's (2010) propositions on al-wasatiyyah are wider than the dimensions of al-wasatiyyah in Hassan's (2013) work. Summarily, based upon the behavioural principles enshrined in the Qur'an, hadith, and scholars' writings on al-wasatiyyah, the following items (variables) are extracted by the authors of this paper as follows:

- Working with sincerity/pure intention (niyyah)

- Keeping trust (amanah)

- Performing a job efficiently and perfectly (itqan)

- Maintaining healthy inter-relationship with good faith among employees (at-ta'awun wa at-tarabut)

- Ensuring fairness in task assignment $(a d l)$

- Thinking and working positively with goodness (al-khairiyyah)

- Practicing values in workplace (al-qiam)

- Performing individual responsibilities (al-mas' uliyyah al-fardiyyah)

- Following the middle path to avoid excessiveness in workplace (wasatan)

Subsequently, in this research, all these variables are conceptualised to have positive relationships with employees' job performance. This is as illustrated in Figure 1. 


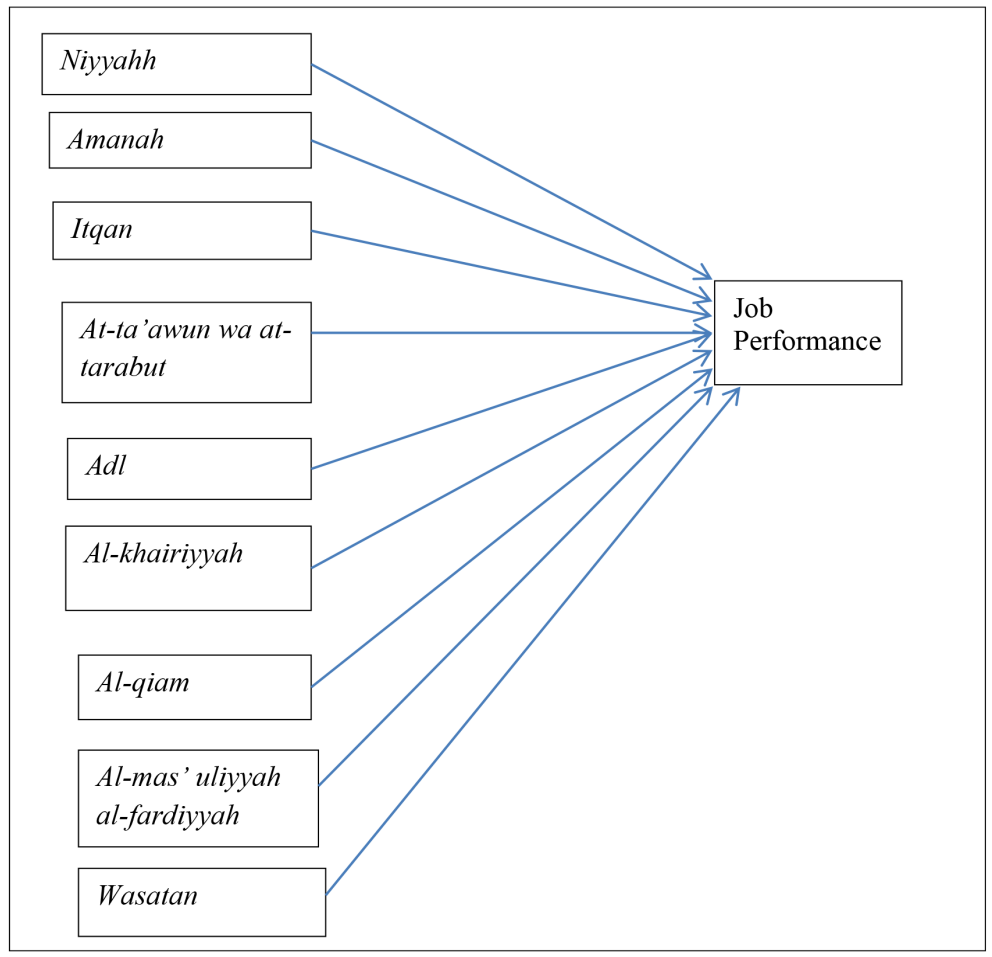

Figure 1. The conceptual framework for al-wasatiyyah variables and job performance

\section{METHODS}

This research is carried out to get the perception of employees on time management in relation to job performance based on the Islamic perspective. A self-explanatory questionnaire in English was designed which consist of two parts: demography (e.g., gender, age, education, and working experience) and questions related to time management and job performance in the organisation from al-wasatiyyah perspective.

The questionnaire was structured in such a way as to make it easier for the respondents to proceed from one question to the next. A 5-point Likert scale ranging from $1=$ strongly disagree to $5=$ strongly agree was used for the questionnaire items. The items on time management were adapted from Macan (1994) and Macan et al.'s (1990) time management behaviour scale. On the other hand, the items on job performance and al-wasatiyyah were developed from the reviews of literature (Abduljabbar et al., 2012; Hassan, 2013; Hanapi, 2014; Ahmad et al., 
2012). The variables on time management, al-wasatiyyah, and job performance are provided in Table 4, Table 8, and Appendix, respectively. Various constructs on time management were generated through the exploratory factor analysis (EFA) of which the details are provided in the "Exploratory Factor Analysis" section.

A pre-test was performed to enhance the clarity of the items and improve face validity of the items. An evaluation form was designed to get feedback on the questionnaire items and communicated with two professors in the first author's department. No major comments were received on the questionnaire items from them except some suggestions of rewording some of the items. A reliability test was also conducted to know whether or not accurate and precise results could be obtained from the measurements made on the study's variables from the instrument used.

\section{Population Sample}

Malaysian Muslim employees who are working in different organisations were the population for this research. In particular, the researchers contacted the employees who were working in the academic, health, financial, pharmaceutical, and telecommunication sectors located in Klang Valley, Malaysia.

To obtain a better response rate, the lead researcher personally distributed the questionnaire following probability sampling procedure. A total of 330 questionnaires were distributed to the respondents of which 223 completed questionnaires (67.57\%) were found valid for further analysis. The sample size was determined following the rule of thumb: five times the number of items in the questionnaire (Hair et al., 2018). According to this rule, the present sample size 223 can be considered as acceptable. After collecting the data, internal consistency was checked by using the Cronbach alpha $(\alpha)$ test.

\section{Data Analysis Procedure}

In order to reduce the number of variables on time management, the EFA was conducted using the principal axis factoring method with varimax rotation and a cut-off value of 0.6 for factor loadings. Finally, the multiple regression analysis was applied considering job performance as the dependent variable (DV) and the factors generated from EFA as the independent variables (IVs). Data analysis was carried out using the SPSS version 25. 


\section{RESULTS AND DISCUSSION}

Results are discussed in two separate parts: In the first part, sections "Demography," "Reliability," "Exploratory Factor Analysis," and "Multiple Regression Analysis" pertain to time management and job performance. In the second part, the section "Relationship between Al-Wasatiyyah and Job Performance" deals with al-wasatiyyah and job performance.

\section{Demography}

Table 1 provides the demographic information of respondents in terms of gender, age, education, and working experience. The percentages of male and female respondents for this research are $48.9 \%$ and $51.1 \%$, respectively. Most (69.1\%) of the respondents' education level is master's degree, while the rest have bachelor's degree $(14.8 \%), \mathrm{PhD}(9.9 \%)$, and diploma (6.3\%). Among all the age groups mentioned in Table 1, 45.6\% of the respondents' age is between 30 to less than 40 years. The highest percentage for working experience lies in the group of less than 5 years $(39.5 \%)$ whereas the second highest is $30 \%$ with 5 to less than 10 years working experience.

Table 1

Demographic information of the respondents $(n=223)$

\begin{tabular}{llcc}
\hline Demographic characteristics & Options & Frequency & Percent \\
\hline \multirow{2}{*}{ Gender } & Male & 109 & 48.9 \\
& Female & 114 & 51.1 \\
& Less than 30 years & 64 & 28.7 \\
& 30 to less than 40 years & 102 & 45.6 \\
& 40 to less than 50 years & 40 & 17.9 \\
& 50 to less than 60 years & 12 & 5.4 \\
60 years and above & 5 & 2.2 \\
Educational level & Diploma & 14 & 6.3 \\
& Bachelor & 33 & 14.8 \\
& Masters & 154 & 69.1 \\
Working experience & PhD & 22 & 9.9 \\
& Less than 5 years & 88 & 39.5 \\
& 5 to less than 10 years & 67 & 30.0 \\
& 10 to less than 20 years & 52 & 23.3 \\
& More than 20 years & 16 & 7.2 \\
\hline
\end{tabular}




\section{Reliability}

The reliability test was conducted to verify the internal consistency of the variables in the constructs. Table 2 provides the Cronbach alpha $(\alpha)$ value for all the three constructs. Since Cronbach alpha $(\alpha)$ values for all the constructs are more than 0.7 , the internal consistency among the variables belonging to the constructs is therefore acceptable.

Table 2

Cronbach alpha $(\alpha)$ value of the three main constructs

\begin{tabular}{ll}
\hline Construct name & Alpha \\
\hline Time management & 0.878 \\
Al-wasatiyyah & 0.776 \\
Job performance & 0.900 \\
\hline
\end{tabular}

\section{Exploratory Factor Analysis}

The EFA was conducted to reduce the number of items in time management. As mentioned in the Methods section, varimax rotation was used to define the factors obtained from the variables. Principal component analysis (PCA) was used for data reduction. A factor loading threshold value of 0.50 was used for retaining items in the factor. Factors were generated for eigenvalue 1.0 or more.

Table 3 displays the EFA results on time management where the Kaiser-MeyerOlkin (KMO) value is 0.777 which is more than the threshold value of 0.50 . Since $\mathrm{KMO}$ value is a measure of sample adequacy, the present sample is deemed to be acceptable. On the other hand, the Bartlett's test of sphericity is highly significant $(p<0.001)$. This means that significant relationships exist among the variables which are necessary to perform the EFA. Therefore, it can be concluded that the data are suitable for the EFA.

The values of communalities of all the variables are more than 0.50 . Therefore, a minimum of $50 \%$ variation in any of the items is explained by the factor model. Eight factors that explained $64.786 \%$ of total variance were obtained from the EFA. The values of factor loading lie between 0.507 and 0.859 . High factor loadings for all the variables imply robustness in the factor model. Four items were excluded as their factor loadings were below 0.50 . The individual items belonging to the eight factors are shown in the third column of Table 4. 
Table 3

Results from EFA on time management

\begin{tabular}{|c|c|c|c|c|c|c|c|c|}
\hline & \multicolumn{8}{|c|}{ Factor } \\
\hline & 1 & 2 & 3 & 4 & 5 & 6 & 7 & 8 \\
\hline T6 & 0.811 & & & & & & & \\
\hline $\mathrm{T} 8$ & 0.643 & & & & & & & \\
\hline $\mathrm{T} 7$ & 0.602 & & & & & & & \\
\hline $\mathrm{T} 5$ & 0.569 & & & & & & & \\
\hline $\mathrm{T} 22$ & & 0.789 & & & & & & \\
\hline $\mathrm{T} 21$ & & 0.759 & & & & & & \\
\hline T20 & & 0.573 & & & & & & \\
\hline T25 & & 0.507 & & & & & & \\
\hline T13 & & & 0.801 & & & & & \\
\hline T14 & & & 0.689 & & & & & \\
\hline T15 & & & 0.623 & & & & & \\
\hline T16 & & & 0.516 & & & & & \\
\hline T28 & & & & 0.701 & & & & \\
\hline T27 & & & & 0.663 & & & & \\
\hline T29 & & & & 0.593 & & & & \\
\hline $\mathrm{T} 2$ & & & & & 0.810 & & & \\
\hline $\mathrm{T} 1$ & & & & & 0.768 & & & \\
\hline $\mathrm{T} 4$ & & & & & 0.618 & & & \\
\hline T19 & & & & & & 0.859 & & \\
\hline T18 & & & & & & 0.833 & & \\
\hline T17 & & & & & & 0.686 & & \\
\hline $\mathrm{T} 23$ & & & & & & & 0.764 & \\
\hline T24 & & & & & & & 0.722 & \\
\hline T26 & & & & & & & & 0.675 \\
\hline T10 & & & & & & & & 0.603 \\
\hline T9 & & & & & & & & 0.583 \\
\hline
\end{tabular}

Note: $\mathrm{KMO}=0.777 ;$ Barlett's test of sphericity, $p<0.001$ 
Table 4

Individual items belonging to the eight factors

\begin{tabular}{|c|c|c|}
\hline $\begin{array}{l}\text { Item } \\
\text { no. }\end{array}$ & Item & The eight factors \\
\hline T5 & I review my goals to determine if they need revision & $\begin{array}{l}\text { F1: Setting Deadlines and } \\
\text { Reviewing Goals (SDRG) }\end{array}$ \\
\hline T6 & $\begin{array}{l}\text { I break complex, difficult projects down into smaller } \\
\text { manageable tasks }\end{array}$ & \\
\hline $\mathrm{T} 7$ & $\begin{array}{l}\text { I set short-term goals for what I want to accomplish in a } \\
\text { few days or week }\end{array}$ & \\
\hline $\mathrm{T} 8$ & $\begin{array}{l}\text { I set deadline for myself when I set out to accomplish a } \\
\text { task }\end{array}$ & \\
\hline $\mathrm{T} 20$ & I do things in order of priority & $\begin{array}{l}\text { F2: Planning Behaviour } \\
\text { (PB) }\end{array}$ \\
\hline $\mathrm{T} 21$ & I feel I use my time effectively & \\
\hline $\mathrm{T} 22$ & I plan beforehand for the day's activities & \\
\hline $\mathrm{T} 25$ & $\begin{array}{l}\text { When I carry out some work-related activities, I pay full } \\
\text { attention to them }\end{array}$ & \\
\hline $\mathrm{T} 13$ & I carry a notebook to jot down notes and ideas & $\begin{array}{l}\text { F3: Time Management } \\
\text { Instrument (TMI) }\end{array}$ \\
\hline T14 & $\begin{array}{l}\text { When I find that I am frequently contacting someone, I } \\
\text { record that person's name, address, and phone number in } \\
\text { a special file }\end{array}$ & \\
\hline T15 & I keep a daily log of my activities & \\
\hline T16 & My desk space in the office is neat and organised & \\
\hline $\mathrm{T} 27$ & $\begin{array}{l}\text { I use my idle time (such as waiting time) for possible } \\
\text { productive activities }\end{array}$ & $\begin{array}{l}\text { F4: Controlling Behaviour } \\
\text { (CB) }\end{array}$ \\
\hline $\mathrm{T} 28$ & $\begin{array}{l}\text { I do not entertain telephone calls when I am carrying out } \\
\text { important activities in my office }\end{array}$ & \\
\hline $\mathrm{T} 29$ & $\begin{array}{l}\text { I avoid participating in social media (such as Facebook } \\
\text { to manage my time in the office). }\end{array}$ & \\
\hline $\mathrm{T} 1$ & I have specific targets in my present job & $\begin{array}{l}\text { F5: Objectives Fulfilment } \\
\text { (OF) }\end{array}$ \\
\hline $\mathrm{T} 2$ & I have measurable targets in my present job & \\
\hline $\mathrm{T} 4$ & $\begin{array}{l}\text { When I decide on what I will try to accomplish in the } \\
\text { short term, I also keep in mind my long-term objectives }\end{array}$ & \\
\hline $\mathrm{T} 17$ & $\begin{array}{l}\text { My workdays are too unpredictable for me to plan and } \\
\text { manage my time to any great extent }\end{array}$ & $\begin{array}{l}\text { F6: Performance under } \\
\text { Disorganisation }(\mathrm{PD})\end{array}$ \\
\hline $\mathrm{T} 18$ & $\begin{array}{l}\text { I have some of my most creative ideas when I am } \\
\text { disorganised }\end{array}$ & \\
\hline
\end{tabular}


Table 4: (continued)

\begin{tabular}{lll}
\hline $\begin{array}{l}\text { Item } \\
\text { no. }\end{array}$ & Item & The eight factors \\
\hline T19 & $\begin{array}{l}\text { When I am somewhat disorganised, I am better able to } \\
\text { adjust to unexpected events }\end{array}$ & \\
T23 & $\begin{array}{l}\text { I prioritise my list in order of importance, not urgency } \\
\text { T24 }\end{array}$ & $\begin{array}{l}\text { F7 : Prioritisation of Tasks } \\
\text { (PT) }\end{array}$ \\
T9 & $\begin{array}{l}\text { I look for ways to increase the work efficiency } \\
\text { T10 }\end{array}$ & $\begin{array}{l}\text { During a workday, I evaluate how well I follow the } \\
\text { schedule I have set down for myself }\end{array}$ \\
T26 & $\begin{array}{l}\text { I try to do the most important tasks during the early } \\
\text { hours of the day }\end{array}$ & \\
\hline
\end{tabular}

\section{Multiple Regression Analysis}

The multiple regression analysis (MRA) was conducted with the eight factors as the IVs and the overall job performance as the DV. The basic purpose of conducting the MRA is to investigate whether any significant relationship exists between time management factors and job performance. The model postulated for this study is:

$$
\mathrm{JP}=\alpha+\beta_{1} \mathrm{SDRG}+\beta_{2} \mathrm{~PB}+\beta_{3} \mathrm{TMI}+\beta_{4} \mathrm{CB}+\beta_{5} \mathrm{OF}+\beta_{6} \mathrm{PD}+\beta_{7} \mathrm{PT}+\beta_{8} \mathrm{US}+e
$$

The full forms of the variable names are provided in Table 4.

Table 5 shows the model summary results including $\mathrm{R}^{2}$ and Adjusted $\mathrm{R}^{2}$ values. Here, the adjusted $\mathrm{R}^{2}$ is 0.342 which means that about $34.2 \%$ variation in DV is explained by the IVs included in the model.

Table 5

Model summary

\begin{tabular}{lcccc}
\hline Model & $\mathrm{R}$ & $\mathrm{R}^{2}$ & Adjusted $\mathrm{R}^{2}$ & Std. error of the estimate \\
\hline 1 & $0.605^{\mathrm{a}}$ & 0.366 & 0.342 & 0.352 \\
a. Predictors: (Constant), SDRG, PB, TMI, CB, OF, PD, PT, US \\
b. Dependent variable: JP
\end{tabular}

In addition, ANOVA (in the context of the MRA) tests the significance of relationships between the DV and the IVs, particularly whether the DV depends on any of the IVs. The test revealed a statistically significant relationship between 
the DV and IVs (see Table 6). This means that job performance depends on all or at least some of the factors of time management.

Table 6

ANOVA results

\begin{tabular}{llccccc}
\hline Model & & Sum of squares & df & Mean square & F & Sig. \\
\hline 1 & Regression & 15.255 & 8 & 1.907 & 15.411 & 0.000 \\
& Residual & 26.480 & 214 & 0.124 & & \\
\hline & Total & 41.735 & 222 & & & \\
\hline
\end{tabular}

The regression model with the "Enter" method was carried out to identify the significant predictors of job performance (JP) from among the eight IVs. The results are shown in Table 7. Setting Deadlines and Reviewing Goals (SDRG) by breaking activities into manageable tasks $(t=1.973, p=0.050)$, Time Management Instrument (TMI) $(t=2.572, p=0.011)$, Prioritisation of Tasks (PT) $(t=4.848$, $p<0.001)$, and Usage of Schedule (US) $(t=3.679, p<0.001)$ are found to have significant relationship with job performance. Other factors are not found to have significant relationship with job performance.

The results are consistent with the findings of Amponsah-Tawiah et al. (2018) in the sense that superior time management skills enhance job performance. The results also concur with Claessens et al. (2007) who assert that employees need to develop better time management skills, especially identifying priorities, remaining organised, and monitoring one's own progress. The present findings also corroborate with the outcome of the empirical research conducted by Abduljabbar et al. (2012). Researchers in both works conclude that time planning (that includes prioritisation of tasks and usage of schedule) and time attitude are positively related to job performance. 
Table 7

Multiple regression coefficients

\begin{tabular}{llccccc}
\hline \multirow{2}{*}{ Model } & & \multicolumn{2}{c}{$\begin{array}{c}\text { Unstandardised } \\
\text { coefficients }\end{array}$} & $\begin{array}{c}\text { Standardised } \\
\text { coefficients }\end{array}$ & \multirow{2}{*}{$t$} & Sig. \\
\cline { 3 - 5 } & & B & Std. error & Beta & & \\
\hline 1 & (Constant) & 1.886 & 0.248 & & 7.601 & 0.000 \\
& SDRG & 0.104 & 0.053 & 0.133 & 1.973 & 0.050 \\
& PB & 0.071 & 0.063 & 0.079 & 1.124 & 0.262 \\
& TMI & 0.127 & 0.049 & 0.210 & 2.572 & 0.011 \\
CB & -0.037 & 0.031 & -0.075 & -1.207 & 0.229 \\
OF & -0.056 & 0.055 & -0.082 & -1.019 & 0.309 \\
& PD & 0.045 & 0.025 & 0.104 & 1.808 & 0.072 \\
PT & 0.143 & 0.029 & 0.284 & 4.848 & 0.000 \\
US & 0.184 & 0.050 & 0.253 & 3.679 & 0.000 \\
\hline
\end{tabular}

\section{Relationship between Al-Wasatiyyah and Job Performance}

The MRA was also conducted with the nine variables of al-wasatiyyah as the IVs and the overall job performance as the DV. Note that unlike the time management items, no EFA was performed for the variables of al-wasatiyyah as its initial number of items is already less. The regression model used is presented below:

$$
\mathrm{JP}=\alpha+\beta_{1} \mathrm{~W}_{1}+\beta_{2} \mathrm{~W}_{2}+\beta 3 \mathrm{~W} 3+\beta 4 \mathrm{~W} 4+\beta_{5} \mathrm{~W}_{5}+\beta_{6} \mathrm{~W}_{6}+\beta_{7} \mathrm{~W}_{7}+\beta_{8} \mathrm{~W}_{8}+\beta_{9} \mathrm{~W}_{9}+\mathrm{e}
$$

The details of the variables are shown in Table 8 .

Table 8

Al-wasatiyyah variables

\begin{tabular}{ll}
\hline Variable code & Variable \\
\hline W1 & $\begin{array}{l}\text { Working with sincerity/pure intention (niyyah) helps in managing time for } \\
\text { better job performance }\end{array}$ \\
W2 & $\begin{array}{l}\text { Keeping trust (amanah) imposed on employees by employer as a means for } \\
\text { better job performance }\end{array}$ \\
W3 & $\begin{array}{l}\text { Performing a job efficiently and perfectly (itqan) as a means for better job } \\
\text { performance }\end{array}$ \\
W4 & $\begin{array}{l}\text { Maintaining healthy inter-relationship with good faith among employees } \\
\text { (at-ta'awun wa at-tarabut) as a means for better job performance }\end{array}$ \\
W5 & $\begin{array}{l}\text { Ensuring fairness in task assignment }(a d l) \text { as a means for better job } \\
\text { performance }\end{array}$ \\
\hline
\end{tabular}

(continued on next page) 
Table 8: (continued)

\begin{tabular}{ll}
\hline Variable code & Variable \\
\hline W6 & $\begin{array}{l}\text { Thinking and working positively with goodness (al-khairiyyah) as a means for } \\
\text { better job performance }\end{array}$ \\
W7 & $\begin{array}{l}\text { Practicing values in working place (al-qiam) as a means for better job } \\
\text { performance }\end{array}$ \\
W8 & $\begin{array}{l}\text { Performing individual responsibility (al-mas' uliyyah al-fardiyyah) on time as a } \\
\text { means for better job performance }\end{array}$ \\
W9 & $\begin{array}{l}\text { Following middle path (wasatan) to avoid excessiveness in working place as a } \\
\text { means for better job performance }\end{array}$ \\
JP & Job performance \\
\hline
\end{tabular}

The $\mathrm{R}^{2}$ and adjusted $\mathrm{R}^{2}$ values of the regression test are found to be 0.326 and 0.298 , respectively. Therefore, only about $30 \%$ of variation in job performance is explained by al-wasatiyyah variables. ANOVA global test result is found to be highly significant (as shown in Table 9). Therefore, at least some, if not all, of the al-wasatiyyah variables are significantly related with job performance.

Table 9

Multiple regression ANOVAa test for al-wasatiyyah

\begin{tabular}{lllllll}
\hline Model & & Sum of squares & df & Mean square & F & Sig. \\
\hline 1 & Regression & 13.614 & 9 & 1.513 & 11.458 & $0.000^{\mathrm{b}}$ \\
& Residual & 28.121 & 213 & 0.132 & & \\
\hline \multicolumn{2}{c}{ Total } & 41.735 & 222 & & & \\
\hline a. Dependent variable: JP & & & & \\
b. Predictors: (Constant), W1 through W9
\end{tabular}

Table 10 shows the individual coefficients of the regression analysis. W1, Sincerity/ pure intention $(t=3.562, p<0.001)$; W5, Ensuring fairness in task assignment $(t=2.186, p=0.030)$; W7, Practicing values in working place $(t=2.577$, $p=0.011)$, and $\mathrm{W} 9$, Following the middle path to avoid excessiveness in working place $(t=2.898, p=0.004)$ are all found to have significant relationship with job performance.

While taking cognizance of the above findings and in the light of surah Al-Asr (especially on the second thrust area: doing righteous deeds), it can be contended that managers need to assign tasks to employees in a fair and equitable manner and that all the executives and employees in the organisation could practise and promote Islamic values and ethics while discharging their job responsibilities. 
Table 10

Multiple regression coefficientsa for al-wasatiyyah

\begin{tabular}{|c|c|c|c|c|c|c|}
\hline \multirow{2}{*}{\multicolumn{2}{|c|}{ Model }} & \multicolumn{2}{|c|}{ Unstandardised coefficients } & \multirow{2}{*}{$\frac{\text { Standardised coefficients }}{\text { Beta }}$} & \multirow{2}{*}{$t$} & \multirow{2}{*}{ Sig. } \\
\hline & & B & Std. error & & & \\
\hline \multirow[t]{10}{*}{1} & (Constant) & 1.912 & 0.248 & & 7.723 & 0.000 \\
\hline & W1 & 0.160 & 0.045 & 0.226 & 3.562 & 0.000 \\
\hline & W2 & 0.063 & 0.045 & 0.101 & 1.415 & 0.158 \\
\hline & W3 & -0.029 & 0.049 & -0.042 & -0.587 & 0.558 \\
\hline & W4 & 0.016 & 0.047 & 0.027 & 0.345 & 0.731 \\
\hline & W5 & 0.109 & 0.050 & 0.164 & 2.186 & 0.030 \\
\hline & W6 & -0.020 & 0.047 & -0.031 & -0.433 & 0.665 \\
\hline & W7 & 0.115 & 0.044 & 0.188 & 2.577 & 0.011 \\
\hline & W8 & 0.056 & 0.035 & 0.107 & 1.573 & 0.117 \\
\hline & W9 & 0.078 & 0.027 & 0.183 & 2.898 & 0.004 \\
\hline \multicolumn{7}{|c|}{ a. Dependent variable: JP } \\
\hline
\end{tabular}

The first al-wasatiyyah variable which is significantly related to job performance has direct link with the following hadith. Narrated by Umar bin Khattab (RA) while on the pulpit, he disclosed that the Messenger of Allah (SWT) said, "The reward of deeds depends upon the intentions and every person will get the reward according to what he has intended. So whoever emigrated for worldly benefits or for a woman to marry, his emigration was for that what he emigrated for" (Sahih Bukhari, vol. 1, book 1, hadith no. 1).

Furthermore, the present findings empirically show that those who follow the middle path in their organisation exhibit superior job performance. Indeed, this is also directly linked with the Qur'anic verse that encourages Muslims to embrace a balanced life (see Al-Baqarah, 2: 143). Allah (swT) also says (Al-Isr'a, 17: 110): "Neither say your prayer loud, nor say it in a low tone." Certainly, Islam prescribes people to follow the middle path in living their lives.

\section{MANAGERIAL IMPLICATIONS}

In view of the findings of this research, managers of organisations can make some policy adjustments in order to further enhance performance of their organisations. It is a well-known fact that an organisation's performance depends, among others, on how the employees utilise their time (Abduljabbar et al., 2012). Notwithstanding, managers can exercise the following practices: 
- Should organise training programs for better time management. Each employee should be encouraged to attend this training. Expert facilitators can shed light on how the people can best utilise their time professionally while working in the organisation. The training can also highlight ways on how to manage their time even at the personal level.

- Time management workshops can be organised where employees can share their ways of managing their own time. By doing so, they can learn from each other.

- Special emphasis should be placed to train employees on how to (1) set deadlines, (2) break activities into manageable tasks, (3) prioritise tasks, and (4) use schedule.

- To keep the employees motivated, there should be fair and equitable distribution of works among employees.

- Managers should lead by examples in managing time. Practicing ethics and good values should be a culture that should permeate every level of the organisation. Managers should also identify all time wasters including non-value added and unnecessary meetings and replace those by more productive activities.

- Managers should also promote the concept of al-wasatiyyah among his/her employees and encourage them to apply the principles of al-wasatiyyah in the organisation as well as in their personal lives.

\section{CONCLUSION}

Successful people utilise their time judiciously. Time is an amanah entrusted by Allah (swT) to every human being. On the Day of Judgement, Allah (swT) will ask how this amanah has been protected, i.e., how a person utilised his or her time in this mundane world. In fact, all the accounts of activities are being recorded in an invisible book. This research highlights two aspects of time management. Firstly, some components of time management have significant positive relationship with job performance. Secondly, al-wasatiyyah concepts in managing time have a significant relationship with job performance. In particular, time management instrument, prioritisation of tasks, and usage of schedules are found to have strong relationship with job performance. At the same time, it is found that four concepts of al-wasatiyyah have positive relationship with job performance. This includes working with sincerity which helps in managing time for better job performance, following the middle path to avoid excessiveness in working place as a means 
for better job performance, practicing values in working place as a means for better job performance, and ensuring fairness in task assignment as a means for better job performance. Hence, it is recommended that managers of organisations take cognizance of the above findings of this research to enhance employee's job performance and consequently boost the performance of the whole organisation.

\section{LIMITATIONS OF THE STUDY}

This study investigated the issue of time management in a quantitative way. It did not employ any qualitative research design. Therefore, to better understand the social analysis of time management, future research can be conducted using qualitative research method. Furthermore, for both quantitative as well as qualitative studies, samples can be drawn from different types of professionals, i.e., those who are working in different industries and possibly from different countries, and not limiting to the Malaysian context only.

\section{ACKNOWLEDGEMENTS}

The authors are grateful to the Ministry of Education Malaysia for the Research Initiative Grant, RIGS15-118-0118. The authors are also thankful to their research assistants, Rezbin Nahar and Md. Muhibbullah for their valuable assistance in preparing this article. Appreciation also goes to the anonymous referees for providing their insightful comments.

\section{REFERENCES}

Ahmad, N. L., Yusuf, A. N. M., Shobri, N. D. M., \& Wahab, S. (2012), The relationship between time management and job performance in event management, Procedia-Social and Behavioral Science, 65, 937-941. https://doi.org/10.1016/j. sbspro.2012.11.223

Al-Qur'an. (2016). The meaning of the Holy Quran, translated by Abdullah Yusuf Ali, Beltsvile, USA: Amanah Publications.

Abduljabbar, A. N., Mahdi, O. R., \& Almsafir, M. K. (2012). Relationship between time management and job performance: Empirical study in Malaysia private university. Journal of Advanced Social Research, 2(10), 427-438.

Al-Jeraisy, K. (2008). Time management from Islamic and administrative perspective (1st ed.). Riyadh: Al Jeraisy Establishment. 
Afsaneh, H. R., Gunnel, J., Suzanne, W., \& Kajsa, L. H. (2019). Time management skills in relation to general self-efficacy and parental sense of competence in individuals with and without cognitive disabilities. Cogent Psychology, 6(1). https://doi.org/ 10.1080/23311908.2019.1655981

Alvarez Sainz, M., Ferrero, A., \& Ugidos, A. (2019). Time management: Skills to learn and put into practice. Education + Training. https://doi.org/10.1108/ET-01-20180027

Amponsah-Tawiah, K., Opata, J., \& Tetteh, S. (2018). Time management: Presenteeism versus management-by-objectives. International Journal of Law and Management, 60(6), 1470-1484. https://doi.org/10.1108/IJLMA-01-2018-0010

Bakir, M., \& Othman, K. (2017). A conceptual analysis of wasatiyyah (Islamic moderation - IM) from Islamic knowledge management (IKM) perspective. Revelation and Science, 7(1), 21-31. https://doi.org/10.32350/jitc.71.02

Bond, M., \& Feather, N. (1988). Some correlates of structure and purpose in the use of time. Journal of Personality and Social Psychology, 55(2), 321-329. https://doi. org/10.1037/0022-3514.55.2.321

Britton, B. K., \& Glynn, S. M. (1989). Mental management and creativity: A cognitive model of time management for intellectual productivity. In J. A. Glover, R. R. Ronning, \& C. R. Reynolds (Eds.), Handbook of creativity (pp. 429-440), New York: Plenum. https://doi.org/10.1007/978-1-4757-5356-1_24

Britton, B. K., \& Tesser, A. (1991). Effects of time-management practices on college grades. Journal of Educational Psychology, 83(3), 405-410. https://doi. org/10.1037/0022-0663.83.3.405

Claessens, B. J. C., van Eerde, W., Rutte, C. G., \& Roe, R. A. (2007). A review of the time management literature. Personnel Review, 36(2), 255-276. https://doi. org $/ 10.1108 / 00483480710726136$

Francis-Smythe, J. A., \& Robertson, I. T. (1999). On the relationship between time management and time estimation. British Journal of Psychology, 90(3), 333-347. https://doi.org/10.1348/000712699161459

Green, P., \& Skinner, D. (2005). Does time management training work? An evaluation. International Journal of Training and Development, 9(2), 126-139. https://doi. org/10.1111/j.1468-2419.2005.00226.x

Grissom, J., Loeb, S., \& Mitani, H. (2015). Principal time management skills: Explaining patterns in principals' time use, job stress, and perceived effectiveness. Journal of Educational Administration, 53(6), 773-793. https://doi.org/10.1108/JEA-092014-0117

Hair, J., Black, W. C., Babin, B. J., \& Anderson, R. E. (2018). Multivariate data analysis (8th ed.). Upper Saddle River, New Jersey: Pearson Education, Inc.

Hanapi, M. S. (2014). The wasatiyyah (moderation) concept in Islamic Epistemology: A case study of its implementation in Malaysia. International Journal of Humanities and Social Science, 4(9), 51-62.

Hassan, M. K. (2013). The need to understand al-wasatiyyah as part of IIUM's mission of Islamisation. Kuala Lumpur: IIUM Press. 
Hamid, M. S. A., Islam, R., \& Manaf, N. H. (2014). Employability skills development approaches: An application of the analytic network process. Asian Academy of Management Journal, 19(1), 93-111.

Janeslätt, G. K., Holmqvist, K. L., White, S., \& Holmefur, M. (2018). Assessment of time management skills: Psychometric properties of the Swedish version. Scandinavian Journal of Occupational Therapy, 25(3), 153-161. https://doi.org/10.1080/1103 8128.2017.1375009

Johari, J., Shamsudin, F. M., Yean, T. F., Yahya, K. K., \& Adnan, Z. (2019). Job characteristics, employee well-being, and job performance of public sector employees in Malaysia. International Journal of Public Sector Management, 32(1), 102-119. https://doi.org/10.1108/IJPSM-09-2017-0257

Jone, S. (1997). How to be a better time manager (1st ed.). London: Licensing Agency.

Kamali, M. H. (2010). Moderation and balance in Islam: The quranic principle of wasatiyyah. Kuala Lumpur: International Institute of Advanced Islamic Studies Press.

Karakose, T. (2015). The relationship between medical students' time management skills and academic achievement. Studies on Ethno-Medicine, 9(1), 19-24. https://doi. org/10.1080/09735070.2015.11905418

Kenayathulla, H. B., Ahmad, N. A., \& Idris, A. R. (2019). Gaps between competence and importance of employability skills: Evidence from Malaysia. Higher Education Evaluation and Development, 11(2), 97-112. https://doi.org/10.1108/HEED-082019-0039

Koch, C. J., \& Kleinmann, M. (2002). A stitch in time saves nine: Behavioural decision making explanations for time management problem. European Journal of Work and Organizational Psychology, 11(2), 199-217. https://doi. org/10.1080/13594320244000120

Konig, C. J., \& Kleinmann, M. (2005). Deadline rush: A time management phenomenon and its mathematical description. The Journal of Psychology, 139(1), 33-45. https://doi.org/10.3200/JRLP.139.1.33-45

Kouali, G., \& Pashiardis, P. (2015). Time management profiles of Cypriot school principals: A mixed-methods approach. International Journal of Educational Management, 29(4), 492-518. https://doi.org/10.1108/IJEM-02-2014-0019

Macan, T. H. (1994). Time management: Test of a process model. Journal of Applied Psychology, 79(3), 381-391. https://doi.org/10.1037/0021-9010.79.3.381

Macan, T. H., Shahani, C., Dipboye, R. L., \& Philips, A. P. (1990). College students' time management: Correlations with academic performance and stress. Journal of Educational Psychology, 82(4), 760-768. https://doi.org/10.1037/00220663.82 .4 .760

Mujani, W. K., Rozali, E. A., \& Zakaria, N. J. (2015). The wasatiyyah (moderation) concept: Its implementation in Malaysia. Mediterranean Journal of Social Sciences, 6(4), 66-72. https://doi.org/10.5901/mjss.2015.v6n4s2p66

Njagi, L. K., \& Malel, J. (2012). Time management and job performance in selected parastatals in Kenya. Australian Journal of Business and Management Research, 2(5), 19-28. 
Oran, A. F. (2009). Time management in higher education: Reforming the credit hour system in Jordan's universities. Education, Business and Society: Contemporary Middle Eastern Issues, 2(1), 32-43. https://doi.org/10.1108/17537980910938460

Pierce, J. L., \& Jussila, I. (2011). Psychological ownership and the organizational context: Theory, research evidence, and application. Cheltenham, UK: Edward Elgar. https://doi.org/10.4337/9780857934451

Sarfraz, H. (2017). Differentiated time management skills between leadership styles: Simplified with a cross-cultural approach. Development and Learning in Organizations, 31(6), 14-18. https://doi.org/10.1108/DLO-02-2017-0009

Sarp, N., Yarpuzlu, A. A., \& Mostame, F. (2005). Assessment of time management attitudes among health managers. The Health Care Manager, 24(3), 228-232. https://doi.org/10.1097/00126450-200507000-00007

Sun, H., \& Yang, X. (2009). Students' pressure, time management and effective learning. International Journal of Educational Management, 23(6), 456-466. https://doi. org/10.1108/09513540910981005

Woodward, G., \& Geissler, J. (1999), Entry level management skills: A retailer's perspective, Journal of Fashion Marketing and Management, 3(2), 109-117. https://doi.org/10.1108/eb022552

Yousif, A. F. (2015). Contextualization of wasatiyyah into the Islamic acts of worship. In A. F. Yousif (Ed.), Applications of wasatiyyah in the contemporary Muslim world (pp. 93-116). Kuala Lumpur: IIUM Press. 